This item was submitted to Loughborough's Research Repository by the author.

Items in Figshare are protected by copyright, with all rights reserved, unless otherwise indicated.

\title{
An extensive family of heterometallic titanium(IV)-metal(III) rings with structure control through templates
}

PLEASE CITE THE PUBLISHED VERSION

https://doi.org/10.1002/anie.201706679

\section{PUBLISHER}

(c) Wiley

VERSION

AM (Accepted Manuscript)

\section{PUBLISHER STATEMENT}

This work is made available according to the conditions of the Creative Commons Attribution-NonCommercialNoDerivatives 4.0 International (CC BY-NC-ND 4.0) licence. Full details of this licence are available at: https://creativecommons.org/licenses/by-nc-nd/4.0/

\section{LICENCE}

CC BY-NC-ND 4.0

\section{REPOSITORY RECORD}

Timco, Grigore A., Antonio Fernandez-Mato, Andreas K. Kostopoulos, Christopher A. Muryn, Robin G. Pritchard, llya Strashnov, Inigo J. Vitorica-Yrezabal, George F. Whitehead, and Richard E. Winpenny. 2019. "An Extensive Family of Heterometallic Titanium(iv)-metal(iii) Rings with Structure Control Through Templates". figshare. https://hdl.handle.net/2134/37377. 


\title{
An extensive family of heterometallic titanium(IV)-metal(III) rings with structure control through templates
}

\author{
Grigore A. Timco*, Antonio Fernandez, Andreas K. Kostopoulos, Christopher A. Muryn, Robin G. \\ Pritchard, llya Strashnov, Inigo J. Vitorica-Yrezebal, George F. S. Whitehead and Richard E. P. \\ Winpenny*
}

\section{Dedications}

Abstract: A family of heterometallic [Cat] $\left.\left[\mathrm{Ti}_{x} \mathrm{MO}_{(\mathrm{x}+1}\right)\left(\mathrm{O}_{2} \mathrm{C}^{\mathrm{t}} \mathrm{Bu}\right)_{2 \mathrm{x}+2}\right]$ rings is reported where Cat $=$ a secondary or tertiary alkyl ammonium ion, $x=7,8$ or 9 and, $M=F^{\prime \prime \prime \prime}, G^{\prime \prime \prime}, \mathrm{Cr}^{\prime \prime \prime}, \ln ^{\prime \prime \prime}$ and $\mathrm{Al}^{\prime \prime \prime}$. The structures are regular polygons with eight-, nine- or ten vertices with each edge bridged by an oxide and two pivalates. The size of the ring formed is controlled by the alkylammonium cation present. In each case a homometallic by-product is found $\left.[\mathrm{Cat}]\left[\mathrm{Ti}_{\mathrm{x}} \mathrm{O}_{(\mathrm{x}+1}\right)\left(\mathrm{O}_{2} \mathrm{C}^{\mathrm{t}} \mathrm{Bu}\right)_{2 x-1}\right]$.

There are many families of polymetallic compounds. Sometimes the "family" is so broadly defined that the membership is almost limitless - "polyoxometallates" for example ${ }^{[1]}$ - and then the resemblances between members of the family can be quite small. For other examples the metal core can be constant but the ligand periphery is varied, for example in the many derivatives of the classic $\left\{\mathrm{Mn}_{12}\right\}$ molecule. ${ }^{[2]}$ Such families grow over a period of time, with one molecule inspiring the synthesis of related compounds. We have been studying a family of rings which began with [Cat] $\left[\mathrm{Cr}_{7} \mathrm{MF}_{8}\left(\mathrm{O}_{2} \mathrm{C}^{t} \mathrm{Bu}\right)_{16}\right]$ rings $^{[3]}(\mathrm{M}=$ a divalent metal ion; $\mathrm{Cat}=$ a secondary ammonium cation) but has expanded as we showed we could vary the trivalent metal present, and the size of the ring by choice of template. ${ }^{[4]}$ These rings can be used as building blocks for oligorotaxanes ${ }^{[5]}$ and for molecular nanoparticles. ${ }^{[6]}$ We wanted to establish an equivalent family from $\left\{\mathrm{M}^{\mathrm{IV}}{ }_{\mathrm{x}} \mathrm{M}^{\mathrm{III}}\right\}$ complexes. This is driven by a desire to create complex diamagnetic polymetallic complexes that could act as diamagnetic hosts into which we could dope supramolecular assemblies that could be used as multi-qubit arrays for quantum information processing ${ }^{[7]}$ While there are many outstanding studies of single qubits, most are in solution phase ${ }^{[8]}$ the challenge to study qubits and multi-qubits in an oriented single crystal is a major one ${ }^{[9]}$ and is the inspiration behind this work.

We decided that $\left[\mathrm{TiO}\left(\mathrm{O}_{2} \mathrm{CR}\right)_{2}\right]$ rings could form the basis for such a family reasoning that a $\mathrm{TiO}^{2+}$ fragment has the same charge and is a similar size to a $\mathrm{CrF}^{2+}$ fragment. Several homometallic $\left\{\mathrm{Ti}_{8}\right\}$ rings have been reported previously, ${ }^{[10]}$ which gave us confidence that this approach was feasible.

The initial target was to make $[\mathrm{Cat}]\left[\mathrm{Ti}_{7} \mathrm{M}\left(\mathrm{O}_{2} \mathrm{C}^{\mathrm{t}} \mathrm{Bu}\right)_{16}\right]$ rings,

[a] Dr. Grigore A, Timco, Dr. Antonio Fernandez, Andreas K. Kostopoulos, Dr Christopher A. Muryn, Dr Robin G. Pritchard, Dr llya, Strashnov, Dr Inigo J. Vitorica-Yrzebal, Dr George F. S. Whitehead, Prof. Richard E. P. Winpenny

The School of Chemistry, The University of Manchester Oxford Road, Manchester, M13 9PL, United Kingdom Email: grigore.timco@manchester.ac.uk richard.winpenny@manchester.ac.uk,

Supporting information for this article is given via a link at the end of the document. where $\mathrm{M}$ is a trivalent metal ion. All manipulations were carried out under $\mathrm{N}_{2}$ with rigorous exclusion of water. The route involves dissolution of an oxo-centred triangle of the trivalent metal initially $\mathrm{Fe}^{\text {III }}$ - in pivalic acid in the presence of di- $n$-propylamine and trimethylacetic anhydride; $\left[\mathrm{Ti}\left(\mathrm{O}^{\prime} \mathrm{Pr}\right)_{4}\right]$ is then added. The octametallic cyclic compound $\left\{\left[{ }^{n} \mathrm{Pr}_{2} \mathrm{NH}_{2}\right]\left[\mathrm{Ti}_{7} \mathrm{FeO}_{8}\left(\mathrm{O}_{2} \mathrm{C} \mathrm{Bu}\right)_{16}\right]\right\} 1$ can be prepared via this route in $90 \%$ yield (Figure $1 \mathrm{a}$ ).
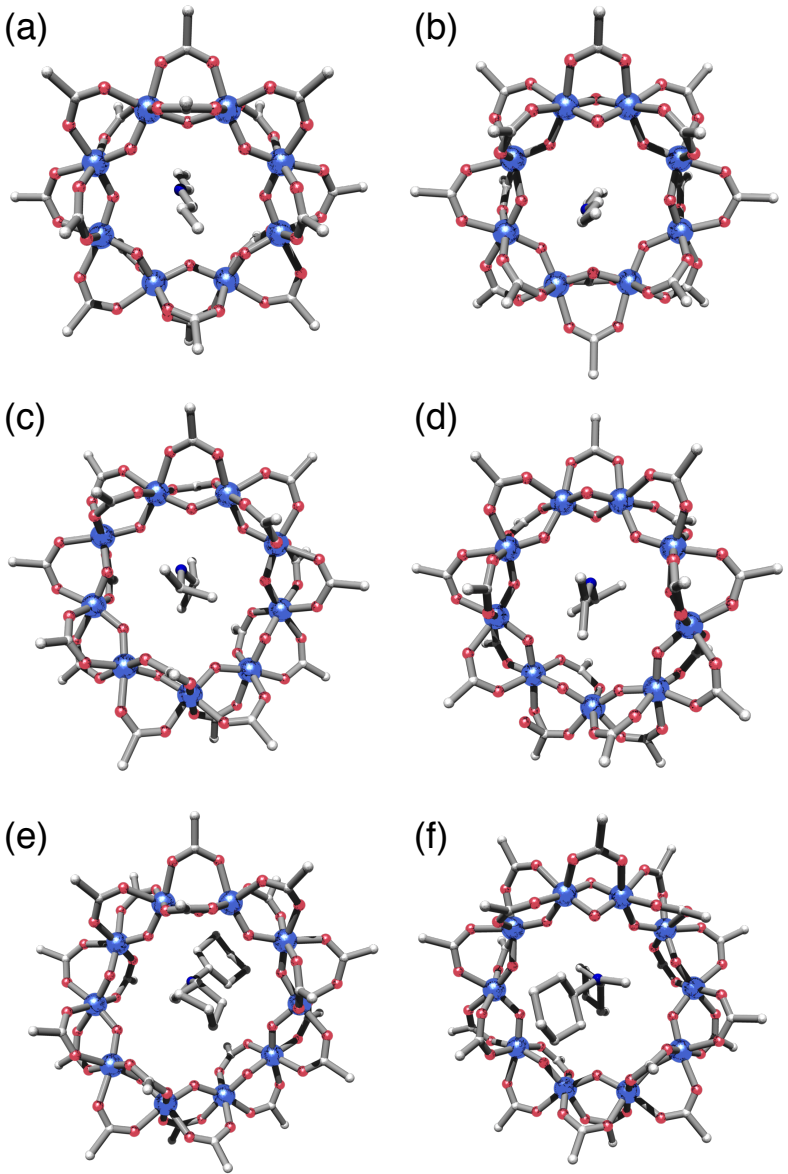

Figure 1. Crystal structures of (a) 1, (b) 6, (c) 7, (d) 9, (e) 10, (f) 11 . Colours: Ti, blue; $\mathrm{O}$, red; $\mathrm{C}$, grey; $\mathrm{N}$, blue. The trivalent metal sites are disordered around the ring. The Ti...Ti edge bridged by two oxides and a pivalate shown top of (b), (d) and (f). $\mathrm{H}$-atoms and Me groups of pivalates excluded for clarity.

We can vary the trivalent metal to make $\left\{\left[{ }^{\mathrm{n}} \mathrm{Pr}_{2} \mathrm{NH}_{2}\right]\left[\mathrm{Ti}_{7} \mathrm{MO}_{8}\left(\mathrm{O}_{2} \mathrm{C}^{\mathrm{t}} \mathrm{Bu}\right)_{16}\right]\right\}$ ( $\mathrm{M}=\mathrm{Ga}$ 2, $\mathrm{Cr} \mathbf{3}, \mathrm{Al} 4$ or In 5). For $\mathrm{Cr}^{\text {III }}, \mathrm{In}^{\text {III }}$ and $\mathrm{Al}$ "I' nitrate salts were used rather than oxo-centered triangles, however it is likely triangles form in situ before $\left[\mathrm{Ti}\left(\mathrm{O}^{\mathrm{P}} \mathrm{Pr}\right)_{4}\right]$ is added. To show that the trivalent ion is included 
within the ring we performed mass spectrometry studies, which showed peaks for the parent ion in each case. An unexpected complexity arises because oxide can displace pivalate in these structures. Therefore in the absence of a trivalent ion the reaction that gives 1, gives a homometallic ring of formula $\left[{ }^{\mathrm{n}} \mathrm{Pr}_{2} \mathrm{NH}_{2}\right]\left[\mathrm{Ti}_{8} \mathrm{O}_{9}\left(\mathrm{O}_{2} \mathrm{C}^{\mathrm{t}} \mathrm{Bu}\right)_{15}\right] 6$ (Figure 1b).

We can control the size of these rings by choice of template: di-iso-propylamine gives enneametallic rings, $\left[\mathrm{Pr}_{2} \mathrm{NH}_{2}\right]\left[\mathrm{Ti}_{8} \mathrm{M}^{\prime \prime \prime} \mathrm{O}_{9}\left(\mathrm{O}_{2} \mathrm{C}^{\dagger} \mathrm{Bu}\right)_{18}\right] \quad(\mathrm{M}=\mathrm{Fe} \quad \mathbf{7}, \mathrm{Ga}$ 8) or [' $\left.\mathrm{Pr}_{2} \mathrm{NH}_{2}\right]\left[\mathrm{Ti}_{9} \mathrm{O}_{10}\left(\mathrm{O}_{2} \mathrm{C}^{t} \mathrm{Bu}\right)_{17}\right] 9$ (Figure 1c and 1d); while N,N-dicyclomethylamine $\left(\mathrm{Cy}_{2} \mathrm{MeN}\right)$ gives decametallic rings $\left\{\left[\mathrm{Cy}_{2} \mathrm{MeNH}\right]\left[\mathrm{Ti}_{9} \mathrm{Fe}^{\text {III }} \mathrm{O}_{10}\left(\mathrm{O}_{2} \mathrm{C}^{\mathrm{B}} \mathrm{Bu}\right)_{20}\right]\right\} \quad \mathbf{1 0}$ and $\left\{\left[\mathrm{Cy}_{2} \mathrm{MeNH}\right]\right.$ $\left.\left[\mathrm{Ti}_{10} \mathrm{O}_{11}\left(\mathrm{O}_{2} \mathrm{C}^{\mathrm{t}} \mathrm{Bu}\right)_{19}\right]\right\} \mathbf{1 1}$ (Figure $1 \mathrm{e}$ and 1f). The nine-metal ring structures are extremely disordered if crystallised from toluene. Crystallisation from ethylacetate/MeCN produces compounds where a full structure can be obtained. This is directly analogous to structural studies of $\left\{\mathrm{Cr}_{8} \mathrm{M}\right\}$ and $\left\{\mathrm{Cr}_{9}\right\}$ rings. ${ }^{11}$ The decametallic rings are noticeably less stable in solution than the octametallic rings: this may be connected with longer $\mathrm{Ti}-\mathrm{O}$ (carboxylate) bonds in these molecules (see below). The homometallic rings 9 and $\mathbf{1 1}$ arise from replacement of pivalate by oxide, as in $\mathbf{6}$ and are best made in the absence of a source of a trivalent metal.

The structures all contain regular polygons of metal sites (Figure 1). The $\mathrm{M}^{\mathrm{III}}$ ion appears to be disordered about the metal polygon and was refined as such; more complex refinement strategies were tried but did not produce better structures. In 1 $5,7,8$ and 10 all $M$....M edges are bridged by a $\mu$-oxide and two pivalates. Each metal site in the ring is six coordinate with two short M...O bonds to the oxides (ranging from 1.746(6) to 1.901(4) $\AA$, similar to the mean Ti-oxide distances of $1.829 \pm$ $0.054 \AA$ in the Cambridge Structural Database). There is one outlier, which is a Ti-O bond of $1.942(4) \AA$ in 5 ; there is no chemical explanation for this long bond. There are four longer bonds to oxygen donors from carboxylates (1.960(8) to 2.15(5) $\AA$, similar to the mean Ti-O(carboxylate) distances of $2.049 \pm$ $0.066 \AA$ in the CSD).

There are variations between structures. The average Ticarboxylate bond length is shorter in 4 (1.91 $\AA$ compared with $2.03 \AA$ in $\mathbf{1}-\mathbf{3}$ and $\mathbf{5})$ and the average Ti-oxide bond length is longer in 5 (1.86 $\AA$ cf. $1.81 \AA$ in $\mathbf{1}$ - 4). This may reflect the presence of an $\mathrm{Al}^{\mathrm{II \prime}}$ ion in 4 and an $\mathrm{In}^{\prime \prime \prime}$ ion in $\mathbf{5}$. The $\mathrm{M}$... O(carboxylate) average bond distances are larger in the nine- and ten-metal rings than in the eight-metal rings, but the M...oxide distances are largely equivalent. In each of 6,9 and 11 one edge is bridged by two oxides and a pivalate, and hence two $\mathrm{Ti}^{\mathrm{il}}$ sites have three oxides and three pivalate oxygens bound. The metric parameters are similar in these structures to those in the heterometallic rings of the same nuclearity.

Each structure incorporates a protonated ammonium cation, which sits at the center of the metal polygon. There are $\mathrm{N}-\mathrm{H} \ldots \mathrm{O}$ $\mathrm{H}$-bonds present in all cases. In the octagons and enneagons, the protonated secondary ammonium cations provides two protons for hydrogen bonding, giving two short contacts (N...O distance 2.869 (13) to $3.102(12) \AA$ ), while in the decagons, the protonated tertiary ammonium cation provides only one proton available for hydrogen bonding, giving a single short contact (N...O distance 3.10(4) to 3.175(5) $\AA$ )

The reactivity of these rings allows formation of the heterometallic rings form homometallic rings. For example, if the regular homometallic ring $\left.\left[\mathrm{TiO}_{(} \mathrm{O}_{2} \mathrm{C}^{\mathrm{t}} \mathrm{Bu}\right)_{2}\right]_{8}$ or the irregular homometallic ring 6 is reacted with a source of $\mathrm{Fe}^{\prime \prime \prime}$ in the presence of $n \mathrm{Pr}_{2} \mathrm{NH}$ and pivalic acid, compound 1 results; it is likely this will be general for the other trivalent metals used and for the nine- and ten-metal rings. This suggests the heterometallic rings have a greater thermodynamic stability than the homometallic rings.

${ }^{1} \mathrm{H}-\mathrm{NMR}$ studies of the diamagnetic rings show resonances for the individual pivalates within the ring (Figure 2 and Figures $\mathrm{S} 1-\mathrm{S} 3$ ). At best the heterometallic rings have $\mathrm{C}_{2}$ symmetry (the axis lying in the plane of the octagon of metals and passing through the heterometal), which would give eight pivalate resonances. We see this for the ${ }^{1} \mathrm{H}-\mathrm{NMR}$ spectrum of $\left\{\mathrm{Ti}_{7} \mathrm{In}\right\} \mathbf{5}$, where we see eight distinct resonances of equal intensity (Figure $2 b)$. For $\left\{\mathrm{Ti}_{7} \mathrm{Ga}\right\}$ and $\left\{\mathrm{Ti}_{7} \mathrm{Al}\right\}$ there are overlaps between some of the pivalates, giving less attractive NMR spectra. Resonances are also seen for the templating ammonium cation. This shows a significant difference for the homometallic ring $\mathbf{6}$, where the asymmetry caused by the presence of two bridging oxides leads to resolution of resonances for the two propyl groups of the cation (Figure 2d).

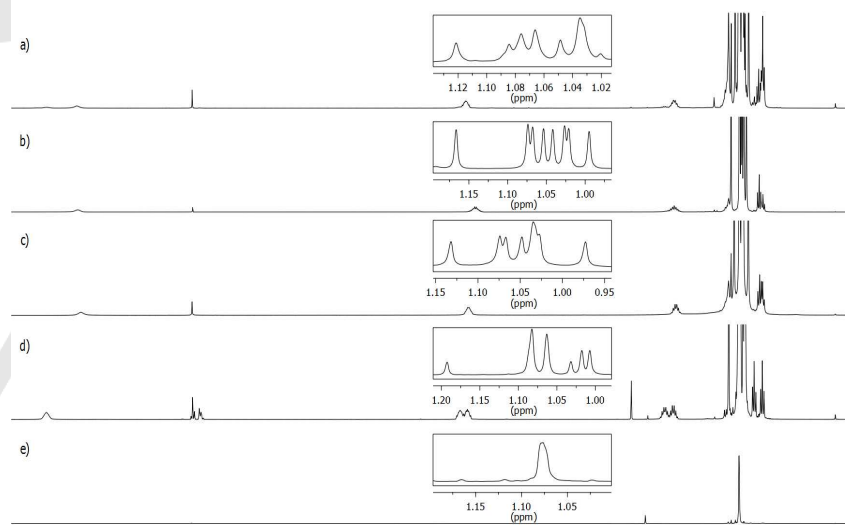

Figure 2. ${ }^{1} \mathrm{H}-\mathrm{NMR}$ spectra $\left(400 \mathrm{MHz}, \mathrm{CDCl}_{3}, 298 \mathrm{~K}\right.$ ) for: a) 4; b) 5; c) 2; d) 6 ; e) a symmetric homometallic ring $\left[\mathrm{Ti}_{8} \mathrm{O}_{8}\left(\mathrm{O}_{2} \mathrm{C}^{\mathrm{t}} \mathrm{Bu}\right)_{16}\right]$. Inset a) to e): expansion of the area containing the pivalate groups.

EPR spectroscopic studies of 1, 3, 7 and 10 were performed to demonstrate that a single paramagnetic trivalent ion was present per ring (Figure 3, Figures S4 and S5). For the rings containing $\mathrm{Fe}^{\text {III }}(S=5 / 2)$ simulations using Easyspin ${ }^{13}$ used the same g-value (2.01) in all cases, and gave: for $1, D=0.178 \mathrm{~cm}^{-}$ ${ }^{1}, E=0.042 \mathrm{~cm}^{-1} ; 7, D=0.175 \mathrm{~cm}^{-1}, E=0.050 \mathrm{~cm}^{-1} ; 10, D=$ $0.118 \mathrm{~cm}^{-1}, E=0.027 \mathrm{~cm}^{-1}$. These values are comparable with the values found for $\left\{\mathrm{FeO}_{6}\right\}$ geometries in malonato, ${ }^{14}$ acetylacetonato $^{14}$ and dipivaloylmethane ${ }^{15}$ complexes.

For 3 the EPR signal suggests that there is a single $\mathrm{Cr}^{\prime \prime \prime}$ ion $(S=$ $3 / 2$ ) in each ring, but that it occupies different sites within the ring (Figure 3d and Figure S5); this is consistent with the X-ray studies as the eight metal sites are subtly different due to the 
proximity to the oxide involved in the $\mathrm{H}$-bond to the protonated amine. The difference is resolved for $\mathrm{Cr}^{\prime \prime \prime}$ but not for $\mathrm{Fe}^{\text {III }}$ as the axial ZFS parameter, $D$, is larger. The EPR spectra were simulated with a single $g_{c r}=1.98$ but with three equal occupancy sites with: $D_{1}=-0.520 \mathrm{~cm}^{-1}, E_{1}=0.036 \mathrm{~cm}^{-1} ; D_{2}=-0.490 \mathrm{~cm}^{-1}, E_{2}$ $=0.020 \mathrm{~cm}^{-1} ; D_{3}=-0.531 \mathrm{~cm}^{-1}, E_{3}=0.028 \mathrm{~cm}^{-1}$. These ZFS parameters are similar to those for $\left\{\mathrm{CrO}_{6}\right\}$ cores. ${ }^{16-18}$
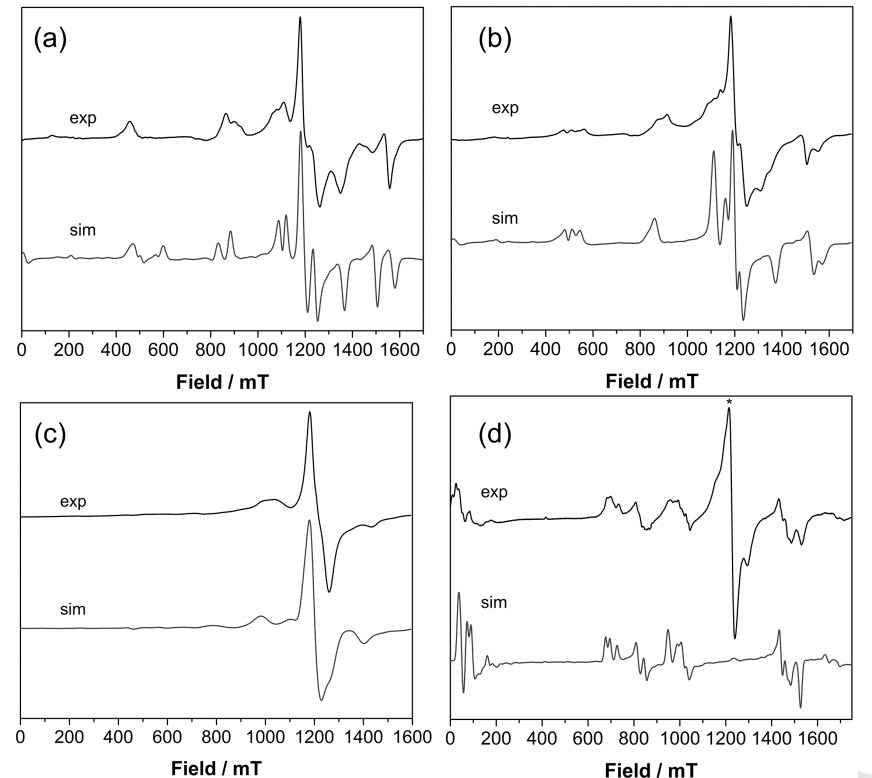

Figure 3. Experimental Q-band (ca. $34 \mathrm{GHz}$ ) EPR spectra and simulations (see text and SI) for (a) 1, (b) 7, (c) 10 and (d) 3 for powder samples at room temperature. For 4 , the broad peak at $\mathrm{g}^{\sim 1.98}$ attributed to a coupled $\mathrm{Cr}^{\prime \prime \prime}$ impurity (most likely a $\mathrm{Cr}_{3} \mathrm{O}$ triangle).

This is the second family of heterometallic rings we have reported. ${ }^{4}$ There is complete control on ring size by choice of templating cation, which is extremely unusual outside our work. Saalfrank and co-workers reported size control of homometallic rings, ${ }^{19}$ while Powell and co-workers have reported $\mathrm{Fe}-\mathrm{Yb}$ heterometallic rings of varying sizes, but not with control of structure through templating. ${ }^{20}$ The compounds reported here are the tip of the iceberg. For $\left\{\mathrm{Ti}_{7} \mathrm{Fe}\right\}$ rings we can further vary the cation to include $\mathrm{Cs}^{+}$or $\mathrm{PrNH}_{3}{ }^{+}$or $\mathrm{Me}_{4} \mathrm{~N}^{+}$and can also vary the carboxylate present. We can also use $\mathrm{N}, \mathrm{N}$-diisopropylethylammonium as a cation to form $\left\{\mathrm{Ti}_{9} \mathrm{M}\right\}$ rings $(\mathrm{M}=$ $\mathrm{Fe}, \mathrm{Ga}, \mathrm{Al}, \mathrm{In})$.

\section{Acknowledgements}

This work was supported by the University of Manchester, the EPSRC(UK, EP/L018470/1) and the National EPR Facility. We also thank EPSRC (UK) for funding an X-ray diffractometer (grant number EP/K039547/1).

Keywords: heterometallic rings, titanium, template synthesis, carboxylates
[2] R. Bagai, G. Christou. Chem. Soc. Rev. 2009, 38, 1011-1026.

[3] F. K. Larsen, E. J. L. Mclnnes, H. El Mkami, J. Overgaard, S. Piligkos, G. Rajaraman, E. Rentschler, A. A. Smith, G. M. Smith, V. Boote, M. Jennings, G. A. Timco, R. E. P. Winpenny, Angew. Chem. Int. Ed. 2003, 42, 101-105.

[4] E. J. L. Mclnnes, G. A. Timco, G. F. S. Whitehead, R. E. P. Winpenny, Angew. Chem. Int. Ed., 2015, 54, 14244-14269

[5] (a) C.-F. Lee, D. A. Leigh, R. G. Pritchard, D. Schultz, S. J. Teat, G. A. Timco, R. E. P. Winpenny, Nature, 2009, 458, 314; (b) B. Ballesteros, T. B. Faust, C.-F. Lee, D. A. Leigh, C. A. Muryn, R. G. Pritchard, D. Schultz, S. J. Teat, G. A. Timco, R. E. P. Winpenny, J. Am. Chem. Soc. 2010, 132, 15435; (c) A. Fernandez, J. Ferrando-Soria, E. M. Pineda, F. Tuna, I. J. Vitorica-Yrezabal, C. Knappke, J. Ujma, C. A. Muryn, G. A. Timco, P. E. Barran, A. Ardavan, R. E. P. Winpenny, Nature Commun. 2016, 7, 10240.

[6] J. Ferrando-Soria, A. Fernandez, E. M. Pineda, S. A. Varey, R. W. Adams, I. J. Vitorica-Yrezabal, F. Tuna, G. A. Timco, C. A. Muryn, R. E. P. Winpenny, J. Am. Chem. Soc. 2015, 137, 7644-7647.

[7] J. Ferrando-Soria, E. Moreno Pineda, A. Chiesa, A. Fernandez, S. A. Magee, S. Carretta, P.Santini, I. J. Vitorica-Yrezabal, F. Tuna, G. A. Timco, E. J. L. Mclnnes, R. E. P. Winpenny, Nature Commun. 2016, 7, 11377.

[8] For example: (a) D. Aguilà, L. A. Barrios, V. Velasco, O. Roubeau, A Repollés, P. J. Alonso, J. Sesé, S. J. Teat, F. Luis, G. Aromí, J. Am. Chem. Soc. 2014, 136, 14215-14222; (b) K. Bader, D. Dengler, S. Lenz, B. Endeward, S. -D. Jiang, P. Neugebauer, J. van Slageren, Nature Commun. 2014, 5, 5304; (c) J. M. Zadrozny, J. Niklas, O. G. Poluektov D. E. Freedman. ACS Cent. Sci. 2015, 1, 488; (d) M. Atzori, L. Tesi, E. Morra, M. Chiesa, L. Sorace, R. Sessoli, J. Am. Chem. Soc. 2016, 138, 2154-2155; (e) K. S. Pedersen, A.-M. Ariciu, S. McAdams, H. Weihe, J. Bendix, F. Tuna, S. Piligkos, J. Am. Chem. Soc. 2016, 138, 5801-5802.

[9] (a) M. Shiddiq, D. Komijiani, Y. Duan, A. Gaita-Ariño, E. Coronado, S. Hill, Nature 2016, 531, 348; (b) S. Nakazawa, S. Nishida, T. Ise, T. Yoshino, N. R. Mori, D. Rahimi, K. Sato, Y. Morita, K. Toyota, D. Shiomi, M. Kitagawa, H. Hara, P. Carl, P. Höfer, T. Takui, Angew. Chem. Int. Ed. 2012, 51, 9860-9864; (c) F. Moro, D. Kaminski, F. Tuna, G. F. S. Whitehead, G. A. Timco, D. Collison, R. E. P. Winpenny, A. Ardavan and E. J. L. McInnes, Chem. Commun. 2014, 50, 91 - 93

[10] (a) H. Barrow, D. A. Brown, N. W. Alcock, H. J. Clase, M. G.H. Wallbridge Chem. Commun. 1995, 1231-1232; (b) P. Piszczek, M. Richert, A. Grodzicki, T. Głowiak, A. Wojtczak. Polyhedron 2005, 24, 663-670; (c) T. Frot, S. Cochet, G. Laurent, C. Sassoye, M. Popall, C. Sanchez, L. Rozes, Eur. J. Inorg. Chem. 2010, 5650-5659.

[11] (a) M. L. Baker, T. Lancaster, A. Chiesa, G. Amoretti, P. J. Baker, C. Barker, S. J. Blundell, S. Carretta, D. Collison, H. U. Güdel, T. Guidi, E. J. L. McInnes, J. S. Möller, H. Mutka, J. Ollivier, F. L. Pratt, P. Santini, F. Tuna, P. L. W. Tregenna-Piggott, I. J. Vitorica-Yrezabal, G. A. Timco, R. E. P. Winpenny, Chem. Eur. J. 2016, 22, 1779; (b) R. E. Woolfson, G. A. Timco, A. E. Chiesa, I. J. Vitorica-Yrezabal, F. Tuna, T. Guidi, E. Pavarini, P. Santini, S. Carretta and R. E. P. Winpenny, Angew. Chem. Int. Ed., 2016, 55, 8856-8859.

[13] S. Stoll, A. Schweiger, J Magn Reson 2006, 178, $42-55$.

[14] D. Collison, A. K. Powell, Inorg. Chem. 1990, 29, 4735-4746.

[15] A. L. Barra, A. Caneschi, A. Cornia, F. Fabrizi de Biani, D. Gatteschi, C. Sangregorio, R. Sessoli, L. Sorace, J. Am. Chem. Soc. 1999, 121, 53025310 .

[16] G. Elbers, S. Remme, G. Lehmann, Inorg. Chem. 1986, 25, 896-897.

[17] S. Sanz, H. M. O'Connor, E. M. Pineda, K. S. Pedersen, G. S. Nichol, O. Monsted, H. Weihe, S. Piligkos, E. J. L. Mclnnes, P. J. Lusby, E. K. Brechin, Angew. Chem. Int. Ed. 2015, 54, 6761-6764.

[18] E. Tancini, M. J. Rodriguez-Douton, L. Sorace, A. -L. Barra, R. Sessoli, A. Cornia, Chem. Eur. J. 2010, 16, 10482-10493.

[19] R. W. Saalfrank, I. Bernt, E. Uller, F. Hampel, Angew. Chem. Int. Ed. 1997, 36, 2482-2484.

[20] A. Baniodeh, C. E. Anson, A. K. Powell, Chem. Sci. 2013, 4, 4354-4361.

[1] D. -L. Long, R. Tsunashima, L. Cronin, Angew. Chem. Int. Ed. 2010, 49, 1736-1758. 


\section{Table of Contents}

\section{COMMUNICATION}
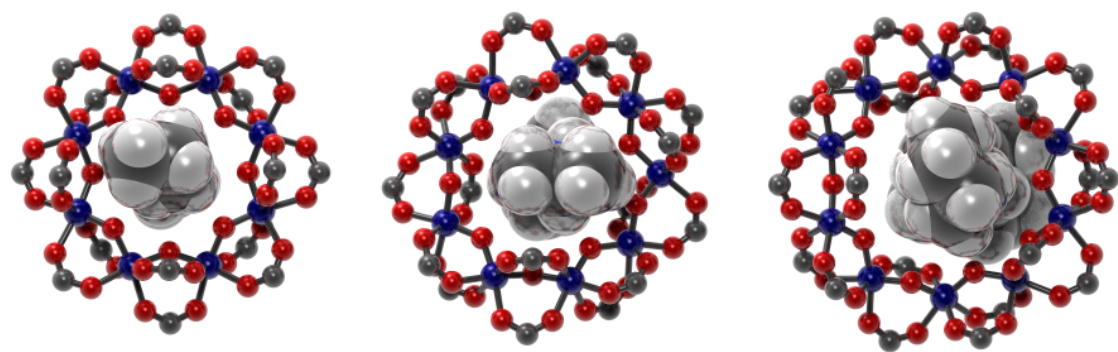

Grigore A. Timco*, Antonio

Fernandez, Andreas $K$. Kostopoulos, Christopher A. Muryn, Robin G. Pritchard, Ilya Strashnov, Inigo J. Vitorica-Yrezebal, George F. S. Whitehead and Richard E. P. Winpenny*

Page No. - Page No.

An extensive family of heterometallic titanium(IV)metal(III) rings with structure control through templates. 